\title{
Strontium diffusion in magnetron sputtered gadolinia-doped ceria thin film barrier coatings for solid oxide fuel cells
}

Steffen Sønderby, Petru Lunca Popa, Jun Lu, Bjarke Holl Christensen, Klaus Pagh Almtoft,

Lars Pleth Nielsen and Per Eklund

\section{Linköping University Post Print}

\section{Tweet}

N.B.: When citing this work, cite the original article.

Original Publication:

Steffen Sønderby, Petru Lunca Popa, Jun Lu, Bjarke Holl Christensen, Klaus Pagh Almtoft, Lars Pleth Nielsen and Per Eklund, Strontium diffusion in magnetron sputtered gadoliniadoped ceria thin film barrier coatings for solid oxide fuel cells, 2013, Advanced Energy Materials, (3), 7, 923-929.

http://dx.doi.org/10.1002/aenm.201300003

Copyright: Not Found

Publisher URL Missing

Postprint available at: Linköping University Electronic Press

http://urn.kb.se/resolve?urn=urn:nbn:se:liu:diva-84610 
DOI: 10.1002/aenm.201300003

Article type: Full Paper

\section{Strontium diffusion in magnetron sputtered gadolinia-doped ceria thin film barrier coatings for solid oxide fuel cells}

Steffen Sфnderby*, Petru Lunca Popa, Jun Lu, Bjarke Holl Christensen, Klaus Pagh Almtoft, Lars Pleth Nielsen, and Per Eklund*

S. Sønderby, Dr. P. Lunca Popa, Dr. J. Lu, Dr. P. Eklund Thin Film Division, Department of Physics, Chemistry and Biology, IFM, Linköping University, SE-581 83 Linköping, Sweden E-mail: stso@dti.dk, perek@ifm.liu.se S. Sønderby, Dr. B. H. Christensen, Dr. K. P. Almtoft, Dr. L. P. Nielsen Danish Technological Institute, Tribology Centre, Teknologiparken, Kongsvang Allé 29, DK8000 Aarhus C, Denmark

Keywords: $\mathrm{Ce}_{0.9} \mathrm{Gd}_{0.1} \mathrm{O}_{2-\delta} ; \mathrm{CGO}$; GDC; $\mathrm{Sr}$ diffusion; X-ray diffraction Abstract:

Strontium (Sr) diffusion in magnetron sputtered gadolinia-doped ceria (CGO) thin films is investigated. For this purpose, a model system consisting of a screen printed $(\mathrm{La}, \mathrm{Sr})(\mathrm{Co}, \mathrm{Fe}) \mathrm{O}_{3-\delta}(\mathrm{LSCF})$ layer, and thin films of $\mathrm{CGO}$ and yttria-stabilized zirconia (YSZ) is prepared to simulate a solid oxide fuel cell. This setup allows observation of $\mathrm{Sr}$ diffusion by observing $\mathrm{SrZrO}_{3}$ formation using X-ray diffraction while annealing. Subsequent electron microscopy confirms the results. This approach presents a simple method for assessing the quality of CGO barriers without the need for a complete fuel cell test setup. CGO films with thicknesses ranging from $250 \mathrm{~nm}$ to $1.2 \mu \mathrm{m}$ are tested at temperatures from $850{ }^{\circ} \mathrm{C}$ to $950{ }^{\circ} \mathrm{C}$ which yields an in-depth understanding of $\mathrm{Sr}$ diffusion through CGO thin films that may be of high scientific and technical interest for implementation of novel fuel cell materials. Sr is found to diffuse along column/grain boundaries in the CGO films but by modifying the film thickness and microstructure the breaking temperature of the barrier can be increased. 


\section{Introduction}

In recent decades, the concerns about the environmental consequences of the increasing fossil fuel combustion have stimulated research into new energy technologies. Among these are solid oxide fuel cells (SOFC) which are capable of converting chemically bound energy directly into electricity at high conversion efficiency. A considerable challenge for commercialization of the $\mathrm{SOFC}$ is high operation temperatures $\left(>800^{\circ} \mathrm{C}\right)$ resulting in high cost for cell core components and interconnects as well as decreased durability due to thermal cycling and corrosion. ${ }^{[1-4]}$ Due to drawbacks of high temperature operation, research has focused on a reduction of the operating temperature to intermediate temperatures of 600$750{ }^{\circ} \mathrm{C}$ through development of novel SOFC materials.

Present-day SOFCs usually consist of a strontium-substituted lanthanum manganite/yttriastabilized zirconia (LSM/YSZ) cathode, an YSZ electrolyte, and a Ni/YSZ composite anode. Of the different approaches to lower the operating temperature several studies have focused on electrolytes and the ability to tailor the microstructure in order to greatly enhance the ionic conductivity. ${ }^{[5-9]}$

Looking at the SOFC system perspective it is insufficient only to improve a single cell component in order to drastically increase the cell performance as it has been shown that all cell components (cathode, electrolyte, and anode) contribute with considerable losses in the SOFC. ${ }^{[10]}$ Therefore, work on novel cathode materials is highly important. Fe-Co perovskites, such as $(\mathrm{La}, \mathrm{Sr})(\mathrm{Co}, \mathrm{Fe}) \mathrm{O}_{3-\delta}(\mathrm{LSCF})$, are an alternative class of cathode materials, instead of the traditional YSZ/LSM cathode, as they have lower polarization resistance. ${ }^{[11-13]}$ Often a composite cathode consisting of LSCF and gadolinia-doped ceria (CGO) is used as it performs superior to the pure LSCF cathode. ${ }^{[14]}$ However, LSCF type cathodes react with $\mathrm{Zr}$ from the YSZ electrolyte to form $\mathrm{SrZrO}_{3}$ which have a detrimental effect on the performance of the cell as this reaction product has a low ionic conductivity compared to YSZ. ${ }^{[15]}$ To avoid 
this reaction a barrier layer needs be applied between the cathode and the electrolyte. CGO is a preferred material for this purpose as it is a good ionic conductor and chemically inert towards YSZ and LSCF at the temperatures of SOFC fabrication and operation. Several studies have showed the capability of CGO as a barrier for Sr diffusion. ${ }^{[16-20]}$

Traditionally, SOFC electrodes have been produced by spraying, tape casting, or screen printing techniques followed by high temperature sintering above $1200{ }^{\circ} \mathrm{C}$. However, at these temperatures CGO and YSZ form a solid solution which has a significantly lower oxide ion conductivity compared to both of the pure compounds. ${ }^{[21-23]}$ An alternative way to fabricate CGO barriers are by physical vapor deposition techniques such as magnetron sputtering, pulsed laser ablation, and electron beam evaporation. ${ }^{[16,20,24]}$ Studies comparing deposition techniques have provided evidence that CGO barrier layers fabricated by reactive magnetron sputtering show better performance. ${ }^{[16,25]}$ This may be associated with higher density of such layers reached at lower temperatures than by wet ceramic deposition techniques. ${ }^{[16,20,21,25]}$ The effectiveness of the sputter deposited CGO as barrier is closely related to the microstructure and density of the film which can be controlled by tuning the deposition parameters such as deposition temperature and substrate bias voltage. ${ }^{[26]}$ As these studies have shown, it is of great scientific interest to understand the $\mathrm{Sr}$ diffusion mechanism in order to tailor the microstructure of the barrier layer in such a way that Sr diffusion may be prevented and the improvements possible by using Fe-Co perovskite based cathodes can be fully utilized. In addition, thin film technology is used in numerous applications resulting in a general interest for understanding diffusion mechanisms in thin films.

In this paper, the diffusion mechanism of $\mathrm{Sr}$ and the formation of $\mathrm{SrZrO}_{3}$ is studied. Furthermore the influence of film thickness and applied substrate bias voltage on the effectiveness of reactively sputtered CGO barriers at different temperatures is investigated. We use a model system consisting of a screen printed and sintered LSCF/CGO composite cathode base layer coated with a CGO barrier layer and a thin YSZ top layer, and study any 
zirconate formation by X-ray diffraction (XRD) while annealing. This approach allows for a simple way of assessing the quality of deposited CGO coatings as diffusion barriers without the need for cell assembling and testing in a dedicated SOFC test setup. At the same time, an in-depth understanding of $\mathrm{Sr}$ diffusion through sputtered $\mathrm{CGO}$ and $\mathrm{SrZrO}_{3}$ formation and is obtained.

\section{Results and discussion}

\subsection{Variation of CGO barrier thickness}

Samples with CGO films of different thicknesses $(250 \mathrm{~nm}, 600 \mathrm{~nm}$, and $1.2 \mu \mathrm{m})$ and a reference sample without CGO film were prepared in order to study the breakage temperature of the CGO barrier. Subsequently an YSZ film was deposited on the CGO coating.

Figure 1 shows $\theta-2 \theta$ x-ray diffractograms for samples annealed at $850{ }^{\circ} \mathrm{C}$. In figure $1 \mathrm{a}$ diffractograms are shown for a sample with YSZ deposited directly on the LSCF/CGO cathode without a CGO barrier layer. The sample has been annealed for $20 \mathrm{~h}$ allowing $40 \mathrm{scan}$ cycles to be conducted. All performed scans are shown in the figure with the first scan (performed after $30 \mathrm{~min}$ ) being placed in the bottom and the last scan $(20 \mathrm{~h})$ in the top. Figure $1 \mathrm{~b}$ presents diffractograms for a sample with a $250 \mathrm{~nm}$ thick CGO barrier which was also annealed for $20 \mathrm{~h}$, resulting in 40 scan cycles. In order to clearly show even weak peaks, only selected scans are presented. Figure 1c shows diffractograms for the sample with a $600 \mathrm{~nm}$ CGO barrier. This sample has been continuously scanned for $61 \mathrm{~h}$, in order to see even the weakest peaks, selected scans are presented.

As the sample without CGO barrier is annealed (figure 1a) a peak is seen to form around $30.5^{\circ}$. This peak corresponds to cubic $\mathrm{SrZrO}_{3}$ (ICDD JCP2 No. 76-167). Most phases of $\mathrm{SrZrO}_{3}$ have an intense peak around $30.5^{\circ}$, however definitive phase identification can be made from TEM investigations described below. The $\mathrm{SrZrO}_{3}$ peak is detected after $\sim 5 \mathrm{~h}$ of annealing and stops growing further in intensity after $\sim 15 \mathrm{~h}$, indicating that the reaction is 
limited by the already formed $\mathrm{SrZrO}_{3}$. In figure $1 \mathrm{~b}$ the $\mathrm{SrZrO}_{3}$ peak also appears, but after $\sim 10 \mathrm{~h}$, and the intensity is also much weaker than was the case when no CGO barrier was applied. This means the $250 \mathrm{~nm}$ thick CGO has some effect but is not capable of completely preventing Sr diffusion at $850{ }^{\circ} \mathrm{C}$. It can be expected that had annealing been carried out for longer time the $\mathrm{SrZrO}_{3}$ peak would become as intense as the peaks observed in the case without barrier as the formed $\mathrm{SrZrO}_{3}$ reaches the maximum thickness for this temperature. In figure 1c no formation of $\mathrm{SrZrO}_{3}$ is observed after $20 \mathrm{~h}$. Therefore, the annealing time has been extended to $61 \mathrm{~h}$, which also did not result in any $\mathrm{SrZrO}_{3}$ formation observable by XRD. Thus, a $600 \mathrm{~nm} \mathrm{CGO} \mathrm{barrier} \mathrm{appears} \mathrm{to} \mathrm{be} \mathrm{capable} \mathrm{of} \mathrm{preventing} \mathrm{Sr}$ diffusion at $850^{\circ} \mathrm{C}$.

Figure 2 shows X-ray diffractograms for samples annealed at $900{ }^{\circ} \mathrm{C}$. In figure 2a all 40 scans performed, on a sample with $600 \mathrm{~nm}$ CGO, during the $20 \mathrm{~h}$ annealing period are shown. The $\mathrm{SrZrO}_{3}$ peak is seen to appear after $\sim 7 \mathrm{~h}$ of annealing and increase in intensity until it reaches a certain level. Figure $2 \mathrm{~b}$ shows selected scans performed on a sample with a $1.2 \mu \mathrm{m}$ thick CGO barrier. In this case no $\mathrm{SrZrO}_{3}$ peak appears showing that at $900{ }^{\circ} \mathrm{C}, 1.2 \mu \mathrm{m} \mathrm{CGO}$ is needed to withstand Sr diffusion. Even though the operation temperature of SOFCs with LSCF cathodes is below these temperatures, the barrier still needs to be able to withstand elevated temperatures during the sintering of the cathode.

Figure 3 shows X-ray diffractograms for the $1.2 \mu \mathrm{m}$ thick CGO barrier annealed at $950{ }^{\circ} \mathrm{C}$. The $\mathrm{SrZrO}_{3}$ peak is appearing within the first $3 \mathrm{~h}$ (6 scan cycles) and rapidly grows to certain intensity after which any further increase is not seen. This indicates the formed $\mathrm{SrZrO}_{3}$ stops growing as diffusion of reactants to the reaction zone is limited. Comparing figure 1a, figure 2a, and figure 3 it is clearly seen that after ended annealing the intensity of the $\mathrm{SrZrO}_{3}$ peak is highest for the sample annealed at highest temperature which indicates a thicker $\mathrm{SrZrO}_{3}$ layer is formed at higher temperatures.

Figure 4 shows a STEM micrograph and EDS mappings of the $600 \mathrm{~nm}$ thick CGO barrier layer after annealing at $900{ }^{\circ} \mathrm{C}$. The EDS mapping of $\mathrm{Sr}$ shows the formation of a $\mathrm{SrZrO}_{3}$ 
layer in the interface between the CGO and YSZ coatings. This finding corresponds to the $\mathrm{SrZrO}_{3}$ peak seen in the $\mathrm{X}$-ray diffractograms (figure 2a). Comparing the mappings of $\mathrm{Fe}$ and Sr shows $\mathrm{SrZrO}_{3}$ only forms in YSZ-CGO interface above the La and $\mathrm{Sr}$ containing LSCF grains in the LSCF/CGO composite. This means the coverage of the insulating $\mathrm{SrZrO}_{3}$ phase is discontinuous and ionic conduction through patches not covered by $\mathrm{SrZrO}_{3}$, should be possible. The Sr mapping also reveals channels of Sr going from the $\mathrm{LSCF}$ to the $\mathrm{SrZrO}_{3}$ grains. This shows the Sr diffusion is not bulk diffusion but grain boundary diffusion which most likely takes place along the column boundaries of the deposited CGO. These findings correspond with earlier reports as grain boundary diffusion of $\mathrm{Sr}$ in $\mathrm{Gd}_{0.2} \mathrm{Ce}_{0.8} \mathrm{O}_{1.9}$ has been found to be $10^{5}$ times larger than the bulk diffusion and both calculations and experiments has shown grain boundaries as the dominant route for Sr diffusion. ${ }^{[24,27,28]}$

Figure 5a shows STEM micrographs and EDS mappings of the YSZ-CGO interface of the $1.2 \mu \mathrm{m}$ barrier layer after annealing at $900{ }^{\circ} \mathrm{C}$. The mapping does not show any sign of $\mathrm{Sr}$ diffusion, and only, by a thorough investigation of the prepared sample an area with a $\mathrm{SrZrO}_{3}$ grain was found (figure $5 \mathrm{~b}$ ). This indicates a $1.2 \mu \mathrm{m}$ thick CGO coating is suitable as a barrier when working at $900{ }^{\circ} \mathrm{C}$ as the formed $\mathrm{SrZrO}_{3}$ grains are too few and scattered to influence the performance of the CGO barrier.

The TEM results shown in figure 4 and figure 5 are in accordance with the observation of $\mathrm{SrZrO}_{3}$ peaks in the $\mathrm{X}$-ray diffractograms in figure 2. This demonstrates the approach of using $\mathrm{XRD}$ as a suitable alternative to preparation and testing of SOFCs in order to assess a number of CGO barriers against each other.

The $\mathrm{SrZrO}_{3}$ grain seen in figure $5 \mathrm{~b}$ is approximately $250 \mathrm{~nm}$ long and has a maximum thickness around $100 \mathrm{~nm}$. At its widest the grain grows into a grain boundary in the CGO layer which shows the grain formed in this boundary as Sr diffused along it from the LSCF. The elongated growth along the CGO-YSZ interface is only approximately $30 \mathrm{~nm}$ thick which 
indicates the diffusion of $\mathrm{Zr}$ is slow compared to $\mathrm{Sr}$ while the stretched out shape point to a high driving force for $\mathrm{SrZrO}_{3}$ formation.

The grain seen in figure $5 \mathrm{~b}$ and the $\mathrm{Sr}$ mapping in figure 4 present almost identical thicknesses of the $\mathrm{Sr}$ phase as the annealing temperature is $900{ }^{\circ} \mathrm{C}$ in both cases. Along the $\mathrm{SrZrO}_{3}$ layer mapped in figure 4 the layer thickness varies regularly which corresponds to grains like the one shown in figure $5 \mathrm{~b}$ forming in the YSZ-CGO interface at the grain boundaries and spreading out along the interface. In figure 4 the density of these grains over the LSCF substrate is so high that when they elongate along the YSZ-CGO interface they come into contact and form a large continuous layer. Sr diffusion into the YSZ layer is observed in the central part of the Sr mapping in figure 4. The Sr appears to be concentrated in channels as it is in the CGO. Keeping in mind the suggested growth mechanism, $\mathrm{Sr}$ is most likely diffusing along grain boundaries in the YSZ due to the high driving force for $\mathrm{SrZrO}_{3}$ formation.

The prepared samples were investigated with SEM/EDS to determine if there were any alternative routes for $\mathrm{Sr}$ diffusion. Cracks, which could not be covered by the deposited films, formed in the LSCF during sintering due to the thermal mismatch between LSCF and Si (see supplementary Information, figure S1). Annealing of the samples during the XRD measurements increased the density of the films but did not induce additional cracks (figure S2). Even though a slight increase in Sr concentration was measured by EDS (Table S1) at the observed cracks, they cannot be a key route for the Sr diffusion detected by XRD due to distance between them.

As vacuum conditions are far from the operational setup of a SOFC system, samples were annealed under atmospheric conditions in a control experiment. Figure 6a shows X-ray diffractograms of samples with $600 \mathrm{~nm}$ thick CGO barriers annealed at under atmospheric conditions. At $900{ }^{\circ} \mathrm{C}$ no $\mathrm{SrZrO}_{3}$ peak is observed whereas at $1000{ }^{\circ} \mathrm{C}$ the phase has clearly been formed. At $950{ }^{\circ} \mathrm{C}$ a weak $\mathrm{SrZrO}_{3}$ may be seen. Figure $6 \mathrm{~b}$ and $6 \mathrm{c}$ show cross-section 
STEM images and EDS mappings of the sample annealed in air at $1000{ }^{\circ} \mathrm{C}$. In figure $6 \mathrm{~b} \mathrm{Sr}$ precipitates are clearly seen in the YSZ layer explaining the Sr peak observed by XRD. In figure $6 \mathrm{c}$ a grain boundary has been mapped. It is seen that the $\mathrm{Sr}$ concentration is enriched along the grain boundary which show this to be the diffusion pathway. These results show the CGO barriers breaks at higher temperatures under atmospheric conditions but the diffusion mechanism is identical to the one observed under vacuum.

\subsection{Effect of substrate bias voltage}

In order to study the impact of substrate bias voltage on the ability of CGO coatings to prevent $\mathrm{Sr}$ diffusion, films were prepared at $-30 \mathrm{~V}$ and $-110 \mathrm{~V}$ substrate bias, while keeping all other parameters constant.

Figure 76 shows selected X-ray diffractograms for a $600 \mathrm{~nm}$ thick CGO sample deposited at $110 \mathrm{~V}$ bias and annealed at $900{ }^{\circ} \mathrm{C}$ (figure $76 \mathrm{a}$ ) and $950{ }^{\circ} \mathrm{C}$ (figure $76 \mathrm{~b}$ ). Looking at figure 76a no $\mathrm{SrZrO}_{3}$ peak is seen indicating the $\mathrm{SrZrO}_{3}$ formation is below the detection limit whereas annealing at $950{ }^{\circ} \mathrm{C}$ (figure $76 \mathrm{~b}$ ) resulted in rapid $\mathrm{Sr}$ diffusion visible after $1 \mathrm{~h}$. This is an obvious improvement compared to the $600 \mathrm{~nm}$ thick film grown at $-30 \mathrm{~V}$ where a $\mathrm{SrZrO}_{3}$ peak was clearly seen in the $\mathrm{X}$-ray diffractogram after $10 \mathrm{~h}$ of annealing at $900{ }^{\circ} \mathrm{C}$ (figure $2 a$ ).

Cross-section SEM micrographs of the films grown at $-30 \mathrm{~V}$ and $-110 \mathrm{~V}$ are shown in figure 87. The CGO grown at $-30 \mathrm{~V}$ bias voltage is clearly columnar whereas columns are not easily recognized in the microstructure of the CGO film grown at $-110 \mathrm{~V}$. The application of a negative substrate bias voltage attracts positively charged ions to bombard and modify the surface of the growing film. Increased negative bias is known to increase the energy flux of bombarding ions which disrupts grain growth, inhibits formation of columns, and results in denser films. ${ }^{[29]} \mathrm{As} \mathrm{SrZrO}_{3}$ formation is not observed by XRD in the film deposited at $-110 \mathrm{~V}$ 
and annealed at $900{ }^{\circ} \mathrm{C}$ it is suggested that the removal of column boundaries eliminates a major route for Sr diffusion through the CGO barrier.

\section{Conclusion}

A model system consisting an LSCF/CGO composite cathode sintered onto a Si wafer and subsequently coated with a CGO film and a YSZ top layer by magnetron sputtering was prepared in order to study Sr diffusion. The thin YSZ top layer allowed Sr diffusion from the LSCF to the CGO-YSZ interface and the subsequent $\mathrm{SrZrO}_{3}$ formation to be probed by XRD. CGO barriers were deposited with different thicknesses and at different substrate bias voltages and were subsequently annealed in vacuum while continuously being scanned by XRD. In this way the breakage temperature of the barriers could be determined by observing the appearance of a $\mathrm{SrZrO}_{3}$ peak in the X-ray diffractograms. TEM and EDS investigation of selected films were performed in order to confirm the conclusions drawn from X-ray diffractograms and to study the Sr diffusion mechanism. For films deposited at $-30 \mathrm{~V}$ it was found that $600 \mathrm{~nm}$ and $1.2 \mu \mathrm{m}$ thick CGO barriers would break at $900{ }^{\circ} \mathrm{C}$ and $950{ }^{\circ} \mathrm{C}$, respectively. TEM investigation confirmed these results.

TEM/EDS showed $\mathrm{Sr}$ diffusion to take place along grain boundaries. At $900{ }^{\circ} \mathrm{C}$ the $\mathrm{SrZrO}_{3}$ formed approximately $100 \mathrm{~nm}$ thick precipitates at the grain boundaries which elongated along the CGO-YSZ interface to form an approximately $30 \mathrm{~nm}$ thick layer. This was attributed to a high driving force for $\mathrm{SrZrO}_{3}$ formation and a limited $\mathrm{Zr}$ diffusion to the reaction zone. Interestingly, it was found that $\mathrm{SrZrO}_{3}$ would only form above $\mathrm{LSCF}$ grains and did not spread enough along the CGO-YSZ interface to form a fully covering layer, leaving patches above CGO grains in the substrate open for conduction of ions.

Some samples were annealed in air to simulate SOFC operation conditions and were subsequently examined by XRD and STEM-EDS. It was found that the diffusion mechanism 
was the same under atmospheric conditions and in vacuum but the breakage temperature was

higher in air.

By depositing at $-110 \mathrm{~V}$ bias instead of $-30 \mathrm{~V}$, the CGO barrier could withstand higher temperatures before Sr diffusion was observed. The effect of increased negative substrate bias is the inhibition of columnar film growth by the energetic ion bombardment. It is suggested that diffusion along column boundaries is a major route for $\mathrm{Sr}$ diffusion.

\section{Experimental Section}

A slurry used for composite LSCF/CGO cathodes with composition 50 wt.\% LSCF - 50 wt.\% CGO $\left(\mathrm{La}_{0.58} \mathrm{Sr}_{0.4} \mathrm{Co}_{0.2} \mathrm{Fe}_{0.8} \mathrm{O}_{3-\delta}-\mathrm{Ce}_{0.9} \mathrm{Gd}_{0.1} \mathrm{O}_{2-\delta}\right)$ was screen printed in an approximately 50 $\mu \mathrm{m}$ thick layer on a Si wafer and sintered at $1000{ }^{\circ} \mathrm{C}$ for 2 hours. On top of the sintered LSCF/CGO cathode material, a CGO barrier layer followed by a YSZ layer were deposited, both by reactive pulsed DC magnetron sputtering. This setup makes up a model system for studying the usefulness of the CGO layer as a barrier for stopping Sr diffusion from the LSCF/CGO cathode to the YSZ layer, which simulate an SOFC electrolyte. The deposited YSZ was $600 \mathrm{~nm}$ thick which made probing of $\mathrm{SrZrO}_{3}$ formation in the YSZ-CGO interface possible by X-ray diffraction.

The YSZ and CGO layers were deposited using a CC800/9 SinOx coating unit from CemeCon AG. CGO ( $\left.\mathrm{Ce}_{0.9} \mathrm{Gd}_{0.1} \mathrm{O}_{2-\delta}\right)$ was deposited from two metallic Ce-Gd (90:10 at.\%) targets of size $88 \times 500 \mathrm{~mm}^{2}$ with a purity of $99.9 \%$ sputtered in an $\mathrm{Ar} / \mathrm{O}_{2}$ atmosphere with a total pressure of $400 \mathrm{mPa}$. The base pressure was below $1 \mathrm{mPa}$. The samples were mounted on a stage carrying out a two-fold planetary motion. A bipolar substrate bias (Pinnacle Plus supply, Advanced Energy) could be applied to the stage and samples. Before starting deposition the samples were pre-heated to $400{ }^{\circ} \mathrm{C}$ whereas the coating temperature was slightly lower. Deposition was performed with a power of $2000 \mathrm{~W}$ on each cathode. Before running the depositions the voltage hysteresis loop for the system was determined. The films 
were grown while running the system in the hysteresis transition region between the metallic and poisoned state of the targets in order to obtain both high deposition rate and stoichiometric films. In order to run the system in the transition region, the cathode current was used as an oxygen partial-pressure feedback signal for controlling the reactive sputtering process.

YSZ $\left(\mathrm{Zr}_{0.84} \mathrm{Y}_{0.16} \mathrm{O}_{2-\delta}\right)$ was deposited from two metallic $\mathrm{Zr}-\mathrm{Y}(84: 16$ at.\%) targets in an $\mathrm{Ar} / \mathrm{Kr} / \mathrm{O}_{2}$ atmosphere. $\mathrm{Kr}$ was added as a sputtering gas as its atomic mass is close to the atomic mass of $\mathrm{Zr}$ and $\mathrm{Y}$ which results in increased momentum transfer that leads to a higher sputter rate but also may be beneficial for the kinetics of film growth. During deposition 3000 W was supplied to each target and a bipolar substrate bias of $-30 \mathrm{~V}$ was applied to the samples. All other deposition parameters were similar to the ones used for depositing CGO. For both YSZ and CGO deposition the purity of all the applied sputtering and reactive gasses were $99.999 \%$.

X-ray diffraction in the $\theta-2 \theta$ geometry was performed with a Philips X'Pert diffractometer equipped with a variable-temperature stage placed in a vacuum chamber. The sample was heated to the desired temperature $\left(850-950{ }^{\circ} \mathrm{C}\right)$ and continuously scanned for the duration of the annealing process. Each scan cycle lasted approximately $30 \mathrm{~min}$. The measurements were carried out at a pressure of $1 \mathrm{mPa}$ using $\mathrm{CuK \alpha}$ radiation. A few samples were annealed under atmospheric condition in a tube furnace (Heraeus, Ro 4/25) and subsequently scanned in the XRD setup at room temperature. This was done for comparison as atmospheric is closer to a real SOFC setup. For determining the film thickness and investigating film morphology scanning electron microscopy (SEM) was performed using a Nova 600 nanoSEM from FEI equipped with an EDAX energy dispersive X-ray spectroscopy (EDS) system. Transmission electron microscopy (TEM) and energy dispersive $X$ ray spectresepy (EDS $\nrightarrow$ in scanning TEM (STEM) were performed on film cross-sections using a Tecnai G2 20 U-Twin 200 kV FEGTEM from FEI and a double-corrected $\operatorname{Titan}^{3} 300 \mathrm{kV}$ TEM also from FEI. Cross-section 
samples were prepared by mechanically polishing down to a thickness of approximately 55

$\mu \mathrm{m}$ followed by ion milling using Precision Ion Polishing System (PIPS; Gatan) operated at 5 $\mathrm{keV}$ and $5^{\circ}$ incident angle with argon ions and a final polishing step at $2 \mathrm{keV}$ for $10 \mathrm{~min}$.

\section{Acknowledgements}

Financial support from Nordforsk ref. no. 9046 (ThinSOFT), Nordic Innovation Centre ref. no. 09046 (Thin-SOFC), and the Swedish Foundation for Strategic Research is acknowledged.

[1] S.J. Litzelman, J.L. Hertz, W. Jung, H.L. Tuller, Fuel Cells 2008, 8, 294.

[2] C. Sun, R. Hui, J. Roller, J Solid State Electrochem. 2010, 14, 1125.

[3] E. D. Wachsman, K. T. Lee, Science 2011, 334, 935.

[4] T. Horita, Y. P. Xiong, H. Kishimoto, K. Yamaji, N. Sakai, H. Yokokawa, J. Power Sources 2004, 131, 293.

[5] M. Sillassen, P. Eklund, N. Pryds, E. Johnson, U. Helmersson, J. Bøttiger, Adv. Funct. Mater. 2010, 20, 2071.

[6] B. Scherrer, S. Heiroth, R. Hafner, J. Martynczuk, A. Bieberle-Hütter, J. L. M. Rupp, L. J. Gauckler, Adv. Funct. Mater. 2011, 21, 3967.

[7] A. Infortuna, A. S. Harvey, L. J. Gauckler, Adv. Funct. Mater. 2008, 18, 127.

[8] K. Kerman, B-K. Lai, S. Ramanathan, Adv. Energy Mater. 2012, 2, 656.

[9] N. I. Karageorgakis, A. Heel, J. L. M. Rupp, M. H. Aguirre, T. Graule, L. J. Gauckler, Adv. Funct. Mater. 2011, 21, 532.

[10] R. Barfod, A. Hagen, S. Ramousse, P.V. Hendriksen, M. Mogensen, Fuel Cells 2006, $6,141$.

[11] A. Mai, V. A. C Haanappel, S. Uhlenbruck, F. Tietz, D. Stöver, Solid State Ionics 2005, 176, 1341. 
[12] F. Tietz, V. A. C. Haanappel, A. Mai, J. Mertens, D. Stöver, J. Power Sources 2006, $156,20$.

[13] C. Sun, R. Hui, J. Roller, J. Solid State Electrochem. 2010, 12, 1125.

[14] E. P. Murray, M. J. Sever, S. A. Barnett, Solid State Ionics 2002, 148, 27.

[15] F. W.Poulsen, N. van der Puil, Solid State Ionics 1992, 53-56, 777.

[16] T. Klemensø, J. Nielsen, P. Blennow, Å. H. Persson, T. Stegk, B. H. Christensen, S. Sønderby, J. Power Sources 2011, 196, 9459.

[17] P. Plonczak, M. Joost, J. Hjelm, M. Søgaard, M. Lundberg, P. V. Hendriksen, J. Power Sources 2011, 196, 1156.

[18] S. Uhlenbruck, T. Moskalewicz, N. Jordan, H.-J. Penkalla, H. P. Buchkremer, Solid State Ionics 2009, 180, 418.

[19] F. P. Van Berkel, Y. Zhang-Steenwinkel, G. Schoemakers, M. Van Tuel, B. G. Rietveld, ECS Trans. 2009, 25, 2717.

[20] S. Uhlenbruck, N. Jordan, D. Sebold, H.P. Buchkremer, V. A. C. Haanappel, D. Stöver, Thin Solid Films 2007, 515, 4053.

[21] A. Mai, V. A.C. Haanappel, F. Tietz, D. Stöver, Solid State Ionics 2006, 177, 2103.

[22] A. Tsoga, A. Gupta, A. Naoumidis, P. Nikolopoulos, Acta Mater. 2000, 48, 4709.

[23] A. Tsoga, A. Naoumidis, D Stöver, Solid State Ionics 2000, 135, 403.

[24] R. Knibbe, J. Hjelm, M. Menon, N. Pryds, M. Søgaard, H. J. Wang, K. Neufeld, J. Am. Ceram. Soc. 2010, 93, 2877.

[25] N. Jordan, W. Assenmacher, S. Uhlenbruck, V. A. C. Haanappel, H. P. Buchkremer, D. Stöver, W. Mader, Solid State Ionics 2008, 179, 919.

[26] F. C. Fonseca, S. Uhlenbruck, R. Nédélec, D. Sebold, H. P. Buchkremer, J. Electrochem. Soc. 2010, 157, B1515.

[27] N. Sakai, H. Kishimoto, K. Yamaji, T. Horita, M. E. Brito, H. Yokokawa, J. Electrochem. Soc. 2007, 154, B1331. 
[28] H. Yokokawa, N. Sakai, T. Horita, K. Yamaji, M. E. Brito, H. Kishimoto, J. Alloys

Compd. 2008, 452, 41.

[29] I. Petrov, P. B. Barna, L. Hultman, J. E. Greene, J. Vac. Sci. Technol. 2003, A21, S117. 


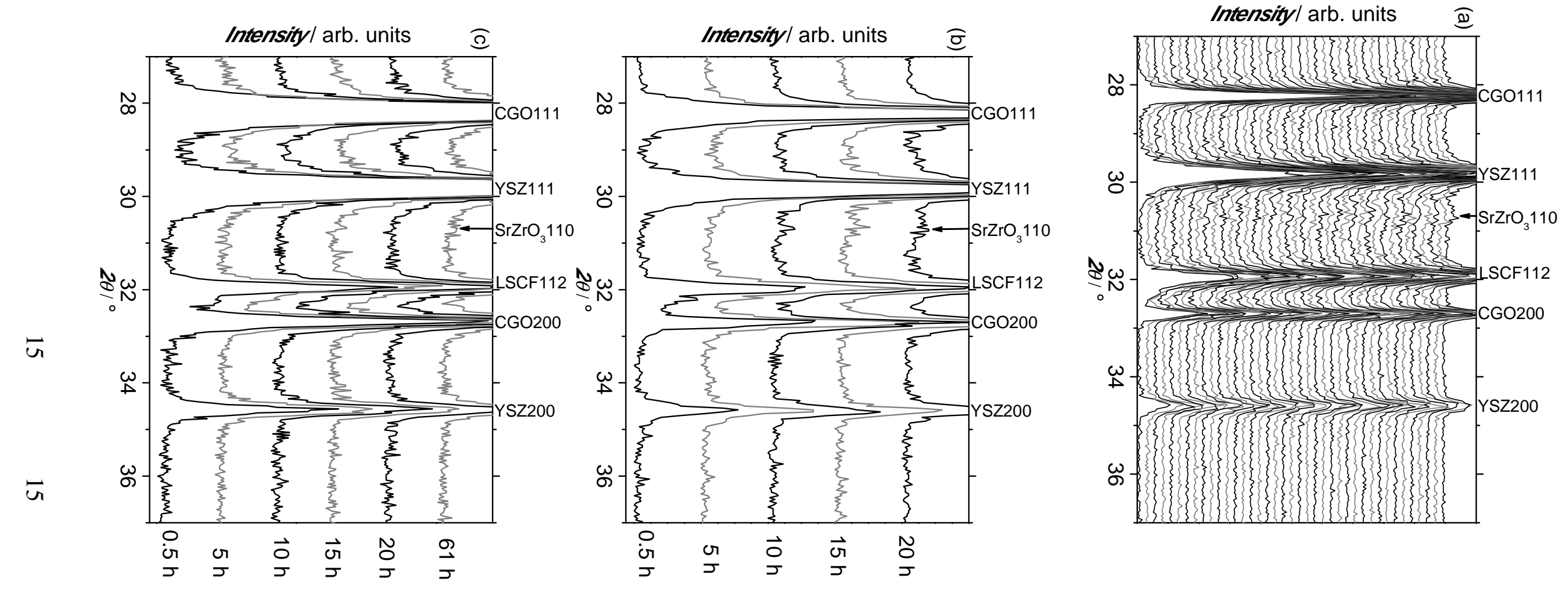


Figure 1. X-ray diffractograms of samples heated to $850{ }^{\circ} \mathrm{C}$ for $20 \mathrm{~h}$ to $61 \mathrm{~h}$. a) Reference sample without a CGO barrier. The sample has been scanned continuously for $20 \mathrm{~h}$, each scan lasting approximately $30 \mathrm{~min}$. Bottom scan after $30 \mathrm{~min}$, top after $20 \mathrm{~h}$. b) Excerpt of scans on sample with $250 \mathrm{~nm}$ CGO barrier. c) Excerpt of scans on sample with $600 \mathrm{~nm}$ CGO barrier.
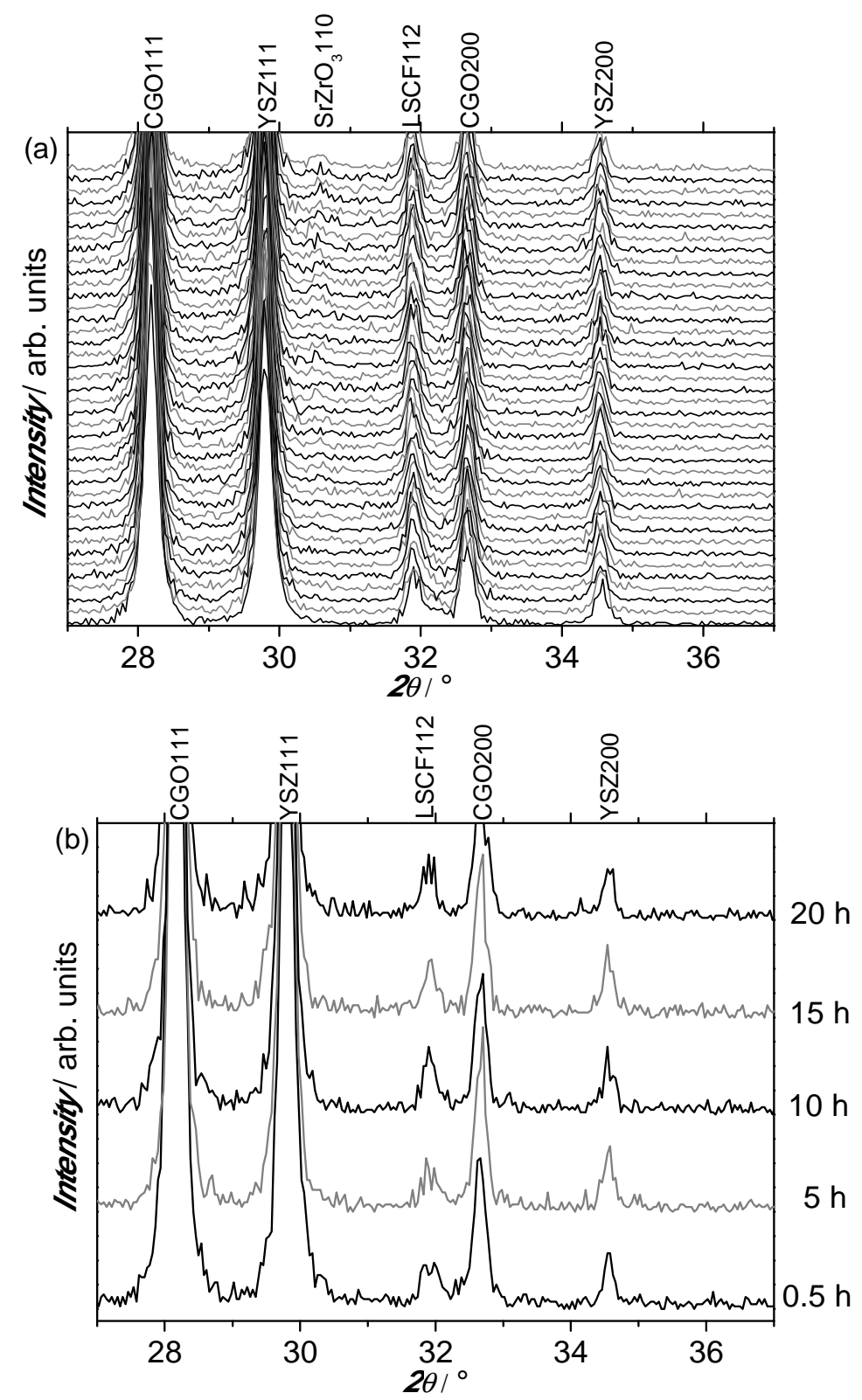

Figure 2. X-ray diffractograms of samples heated to $900{ }^{\circ} \mathrm{C}$ for $20 \mathrm{~h}$. a) Sample with $600 \mathrm{~nm}$ thick CGO barrier. The sample has been scanned continuously, each scan lasting approximately $30 \mathrm{~min}$. Bottom scan after $30 \mathrm{~min}$, top after $20 \mathrm{~h}$. b) Selected scans from sample with $1.2 \mu \mathrm{m}$ CGO barrier. 


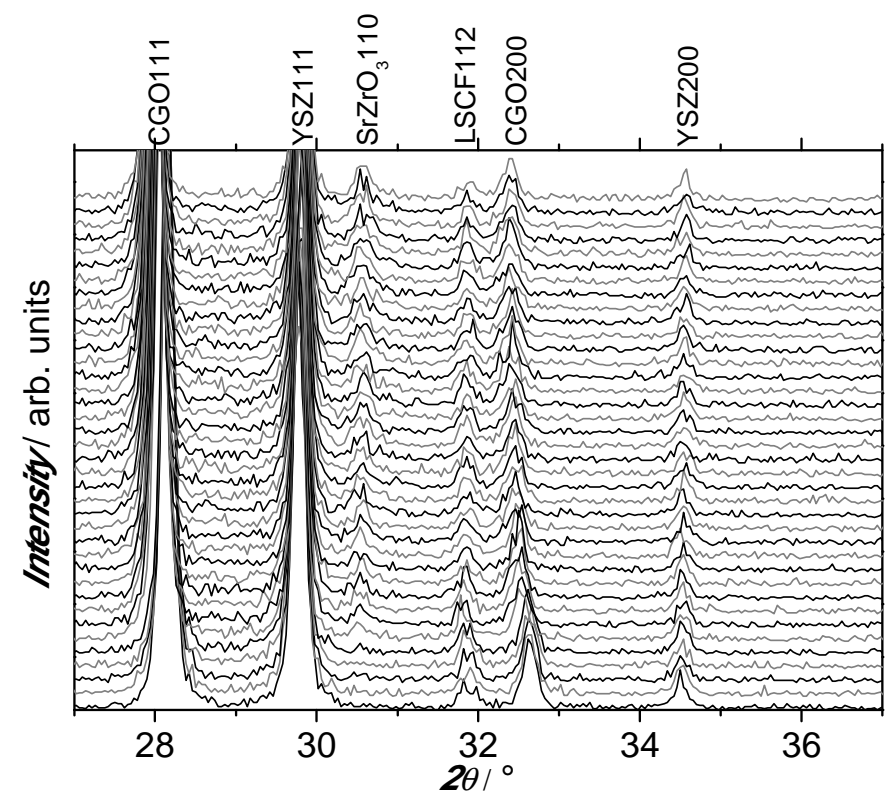

Figure 3. X-ray diffractograms of sample with a $1.2 \mu \mathrm{m}$ thick CGO barrier heated to $950{ }^{\circ} \mathrm{C}$ for $20 \mathrm{~h}$. Bottom scan after $30 \mathrm{~min}$, top after $20 \mathrm{~h}$. 


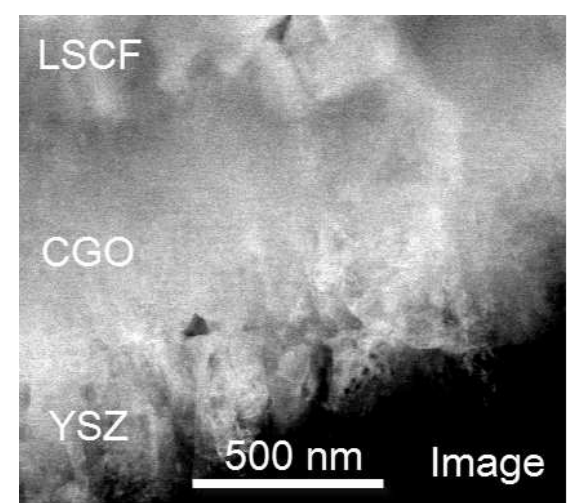

ADVNCED
ANARGD
MAERALS
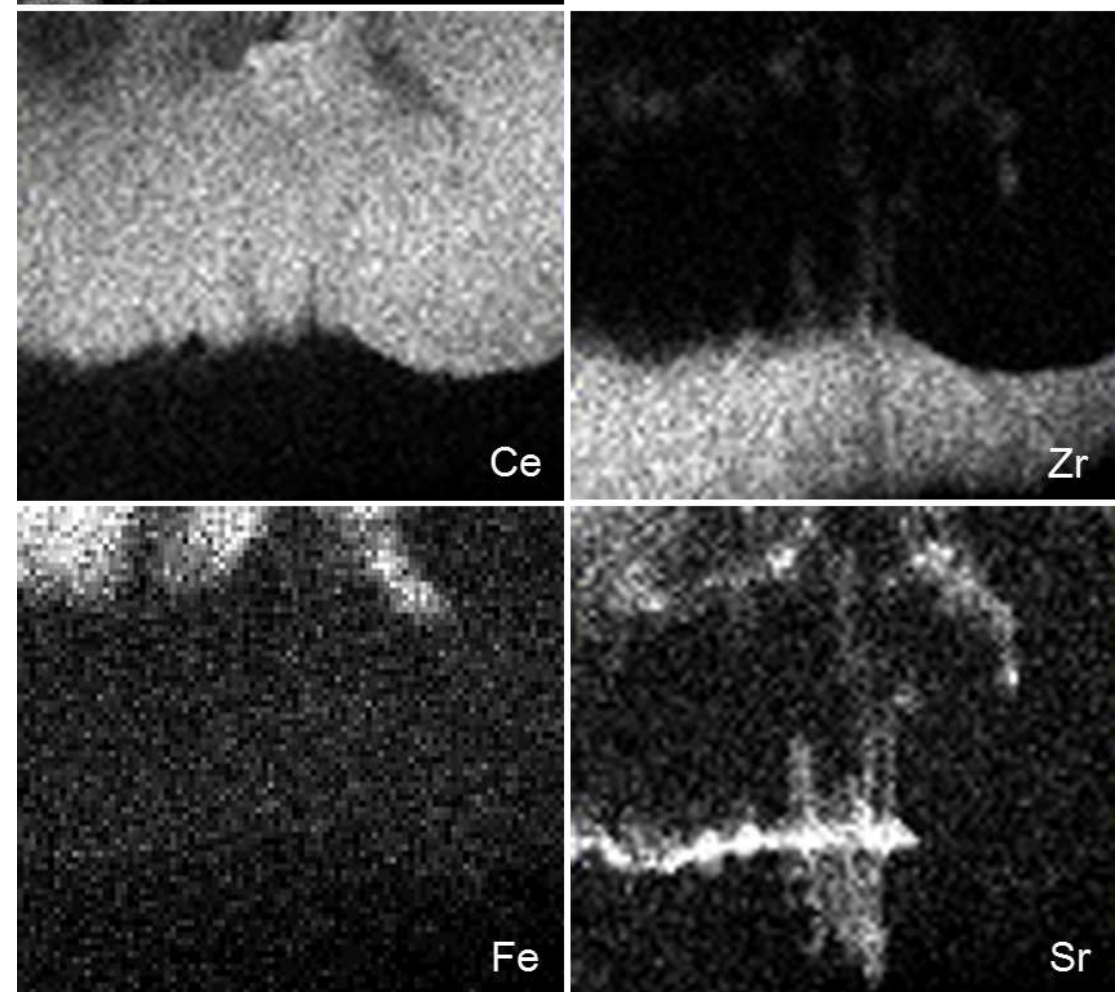

Figure 4. STEM cross-section EDS mapping of the $600 \mathrm{~nm}$ thick CGO barrier annealed at $900{ }^{\circ} \mathrm{C}$. 


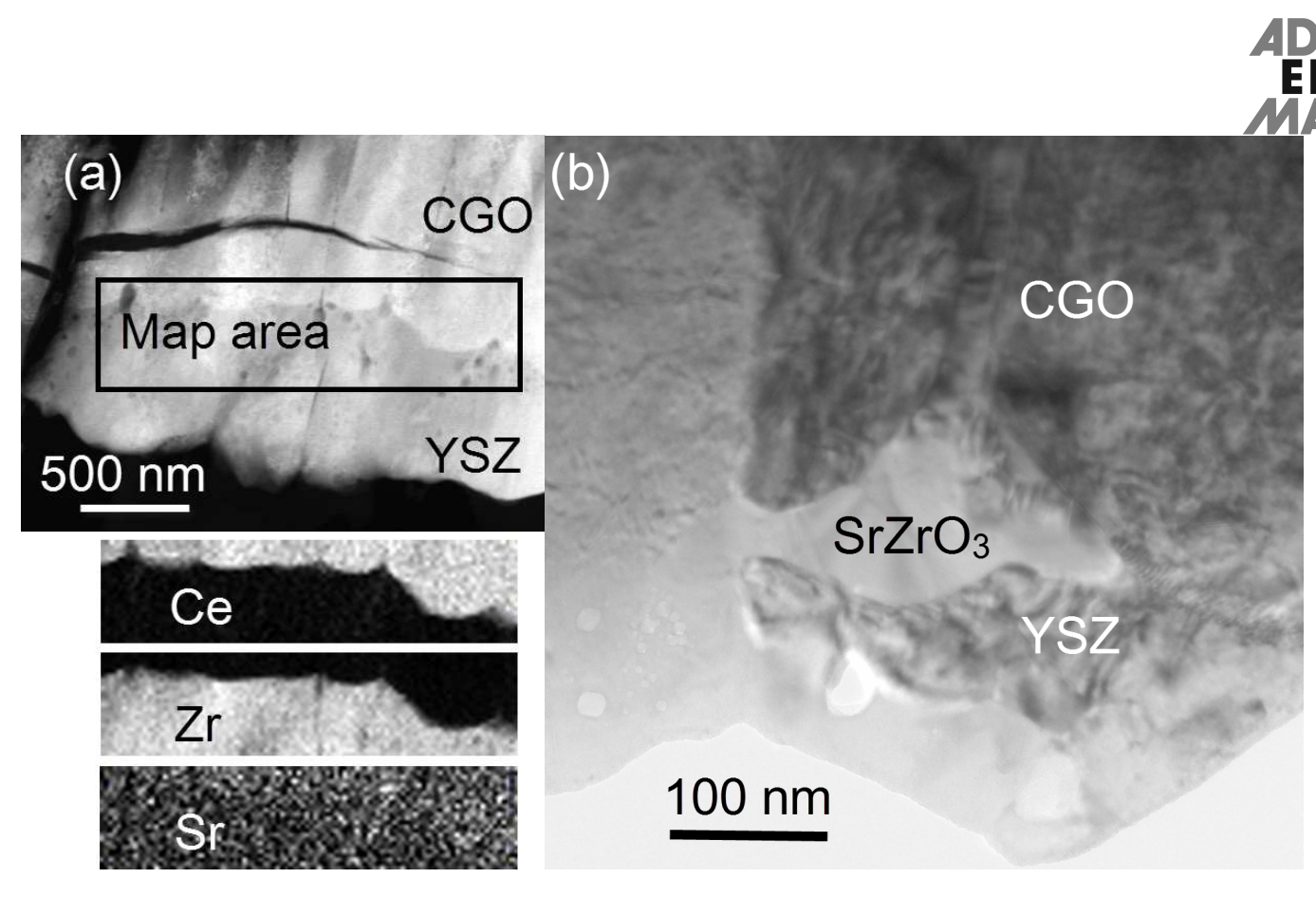

Figure 5. (a) STEM cross-section EDS mapping of YSZ-CGO interface of $1.2 \mu \mathrm{m}$ thick CGO barrier annealed at $900{ }^{\circ} \mathrm{C}$. (b) TEM micrograph of $\mathrm{SrZrO}_{3}$ grain found in the YSZ-CGO interface. 

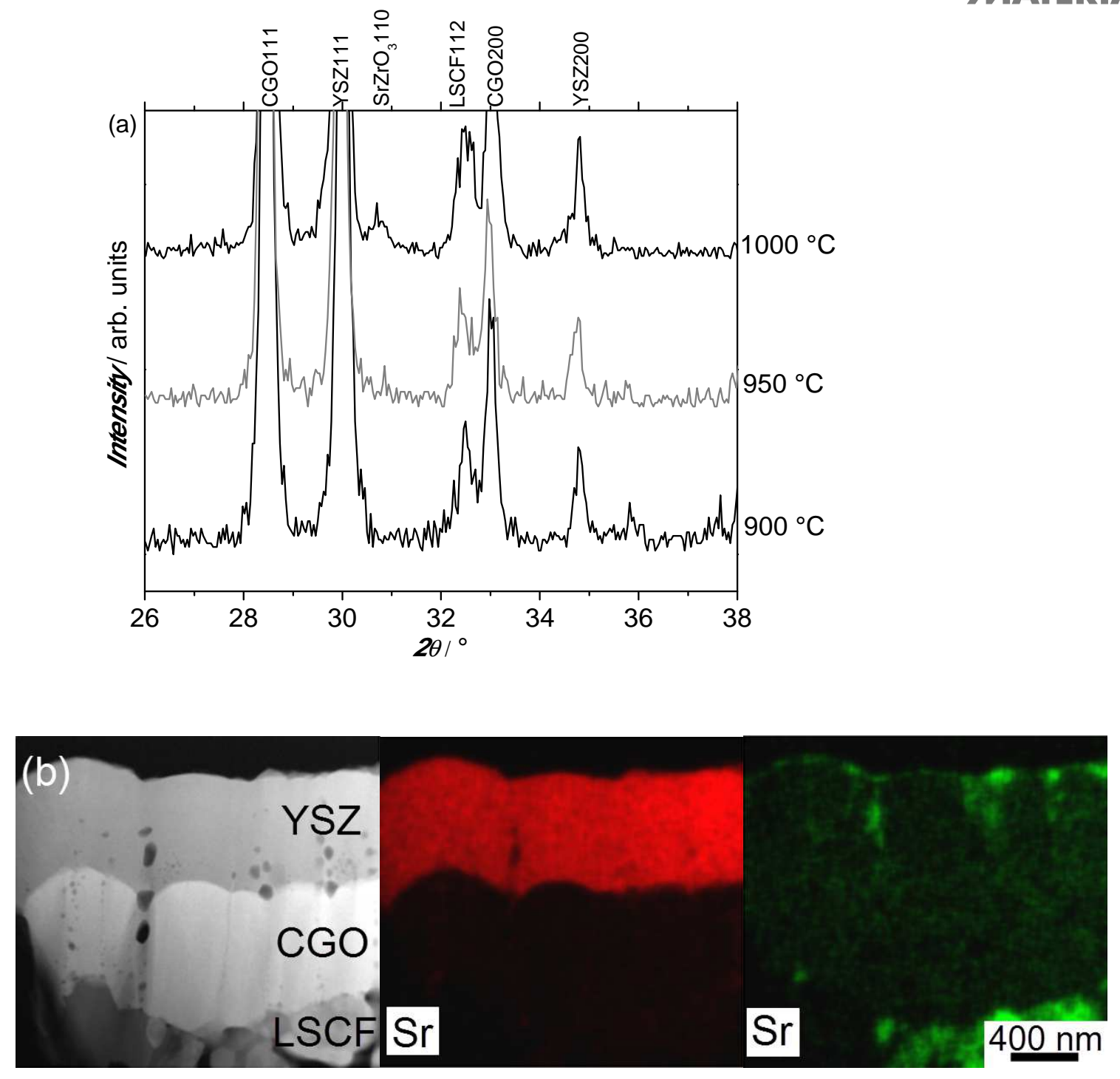


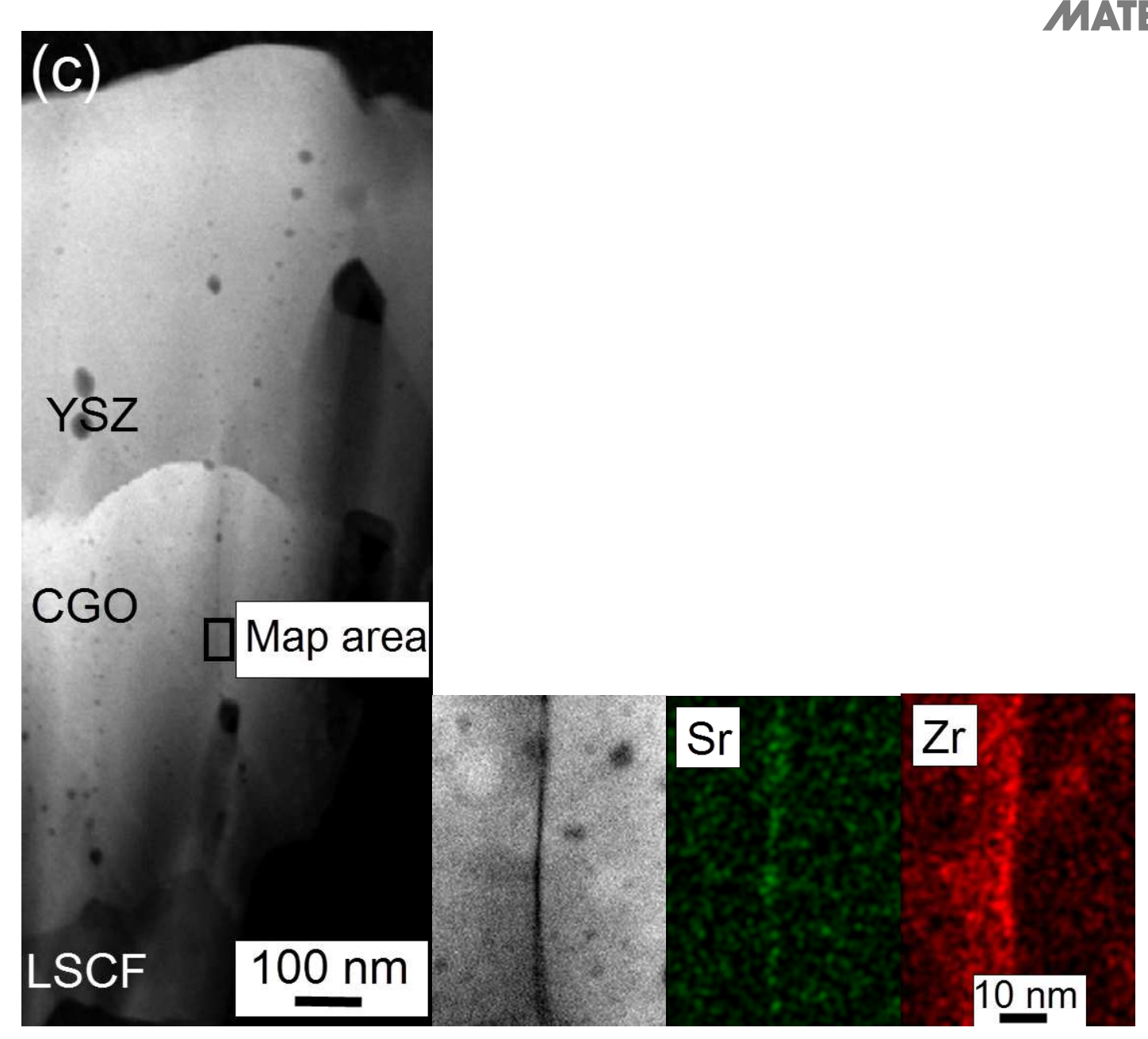

Figure 6. (a) X-ray diffractograms of samples with a $600 \mathrm{~nm}$ thick CGO barrier deposited annealed under atmospheric conditions for $20 \mathrm{~h}$. (b) and (c) STEM cross-sections and EDS mappings of the sample with a $600 \mathrm{~nm}$ barrier annealed at $1000{ }^{\circ} \mathrm{C}$. 

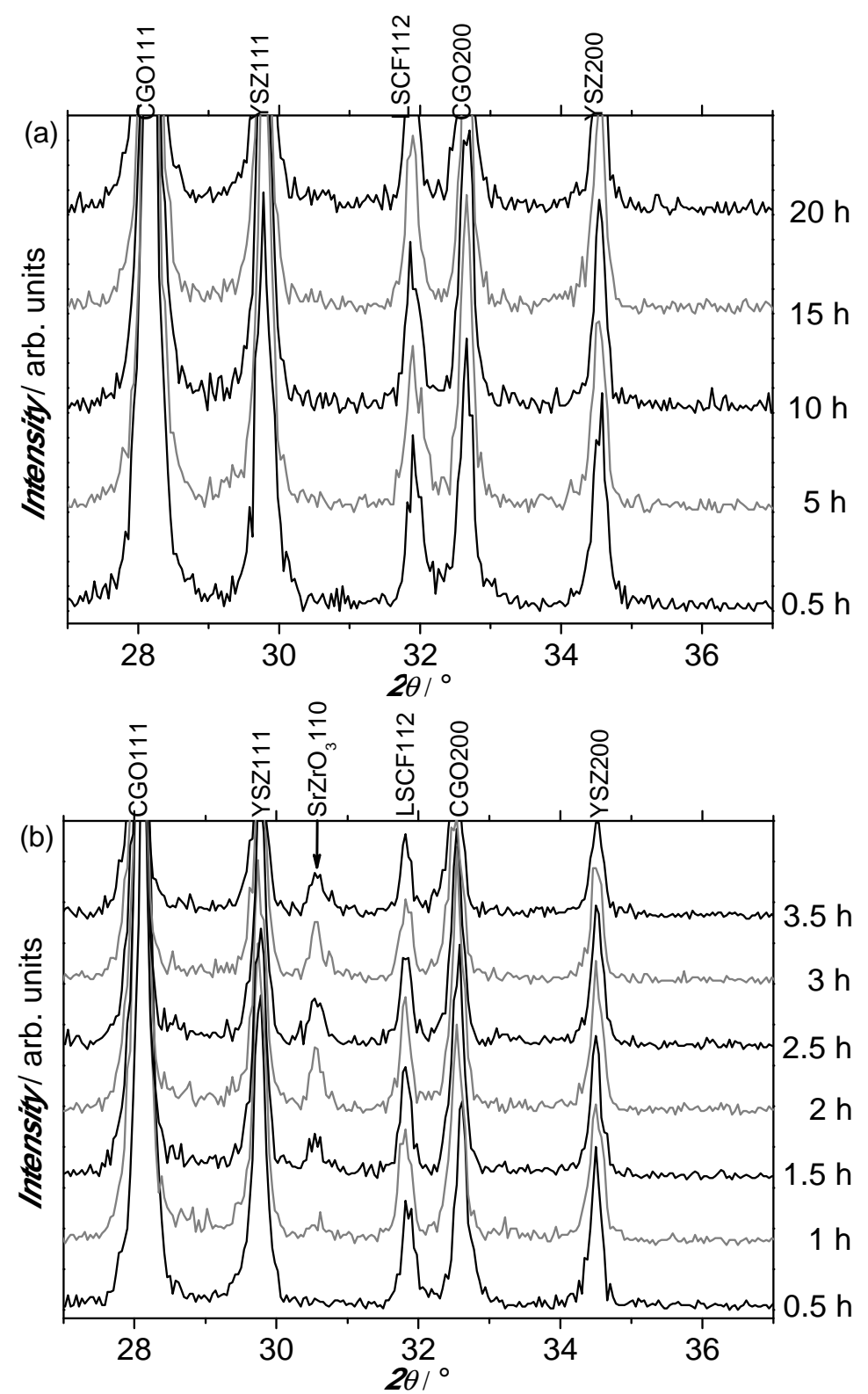

Figure 76. X-ray diffractograms of samples with $600 \mathrm{~nm}$ thick CGO barrier deposited at -110 $\mathrm{V}$ substrate bias voltage. The samples have been annealed at $900{ }^{\circ} \mathrm{C}$ (a) and $950{ }^{\circ} \mathrm{C}(\mathrm{b})$.

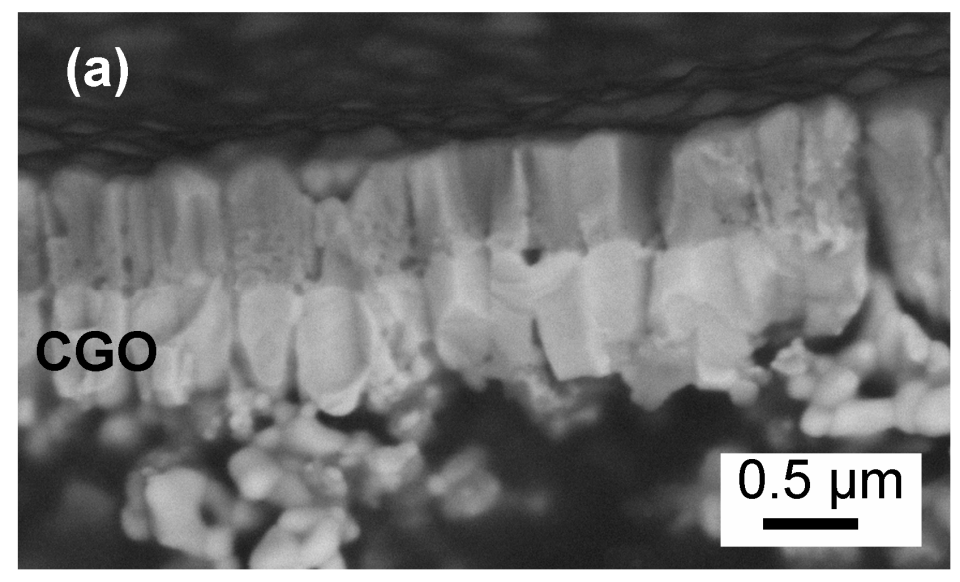




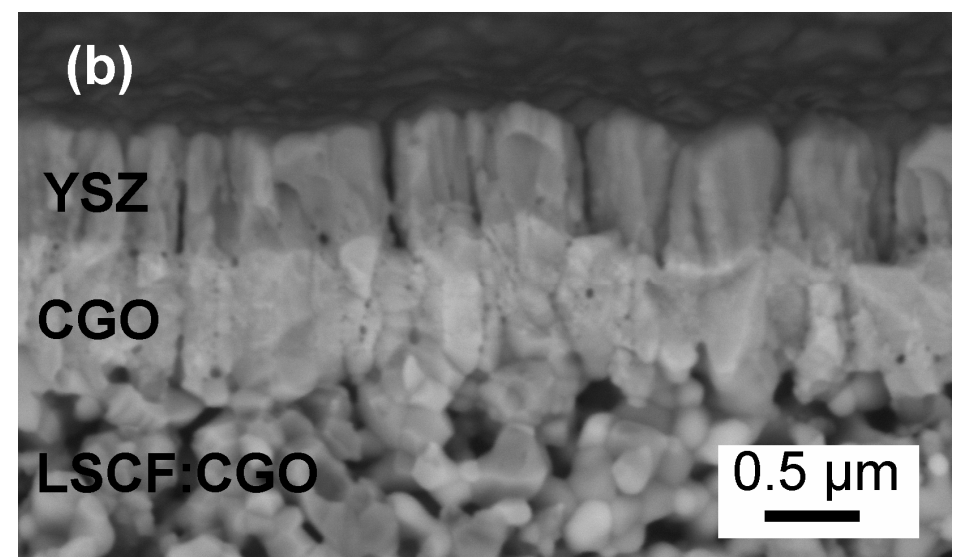

Figure 87. Cross-sectional SEM micrographs of samples after annealing at $900{ }^{\circ} \mathrm{C}$ for $20 \mathrm{~h}$.

Sample deposited at -30 V substrate bias (a) and sample deposited at -110 V substrate bias (b). 
The table of contents entry: Strontium diffusion in magnetron sputtered gadoliniadoped ceria thin film is studied in a model system by X-ray diffraction and electron microscopy. The study shows that diffusion takes place along column boundaries and yields an in-depth understanding of the Sr diffusion mechanism. This also demonstrates how to prepare efficient diffusion barriers for solid oxide fuel cells.

Keyword: Fuel Cells, Thin Films

S. Sønderby*, P. Lunca Popa, J. Lu, B. H. Christensen, K. P. Almtoft, L. P. Nielsen, and P.

Eklund*

Strontium diffusion in magnetron sputtered gadolinia-doped ceria thin film barrier coatings for solid oxide fuel cells

ToC figure:

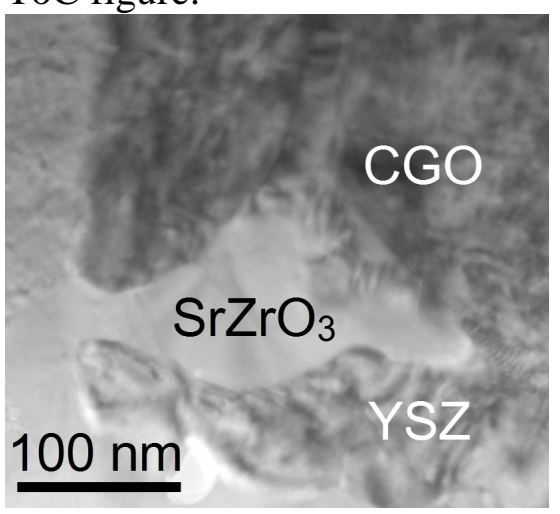




\section{Supporting Information}

for Adv. Energy Mater., DOI: 10.1002/aenm.201300003

Strontium diffusion in magnetron sputtered gadolinia-doped ceria thin film barrier coatings for solid oxide fuel cells

S. Sønderby*, P. Lunca Popa, J. Lu, B. H. Christensen, K. P. Almtoft, L. P. Nielsen, and P. Eklund*
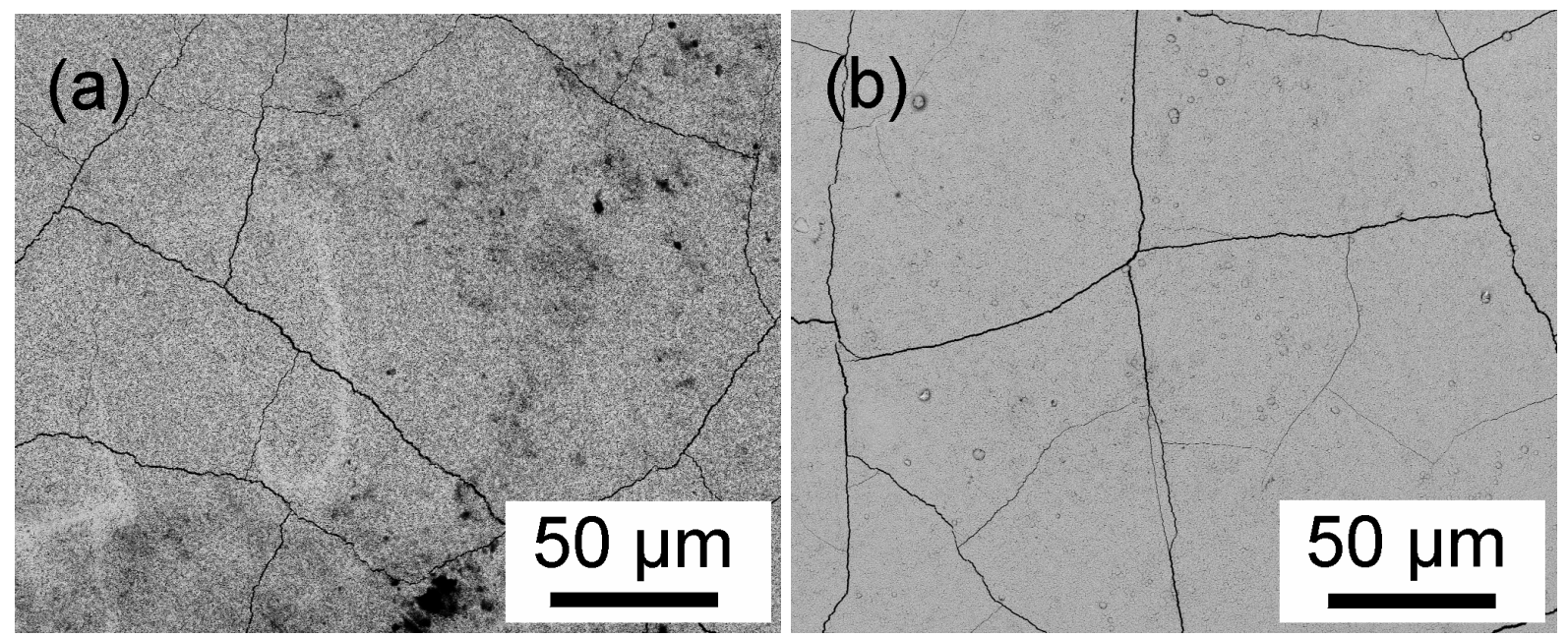

Figure S1. (a) Top-view SEM micrograph of LSCF sintered to silicon. Cracks have appeared during sintering. (b) Top-view SEM micrograph of sample after coating and annealing.

Table S1. Composition of annealed sample determined by EDS at areas with cracks and areas without cracks

\begin{tabular}{ccccccc}
\hline Position & $\begin{array}{c}\mathrm{O} \\
{[\text { At. \%] }}\end{array}$ & $\begin{array}{c}\mathrm{Sr} \\
{[\text { At. \%] }}\end{array}$ & $\begin{array}{c}\mathrm{Y} \\
{[\text { At. \%] }}\end{array}$ & $\begin{array}{c}\mathrm{Zr} \\
\text { [At. \%] }\end{array}$ & $\begin{array}{c}\mathrm{Gd} \\
{[\text { At. \%] }}\end{array}$ & $\begin{array}{c}\mathrm{Ce} \\
\text { [At. \%] }\end{array}$ \\
\hline At crack & 58.4 & 4.5 & 5.2 & 27.0 & 4.2 & 0.7 \\
$\begin{array}{c}\text { Away } \\
\text { from } \\
\text { crack }\end{array}$ & 60.1 & 3.8 & 5.4 & 28.1 & 2.1 & 0.5 \\
\hline
\end{tabular}




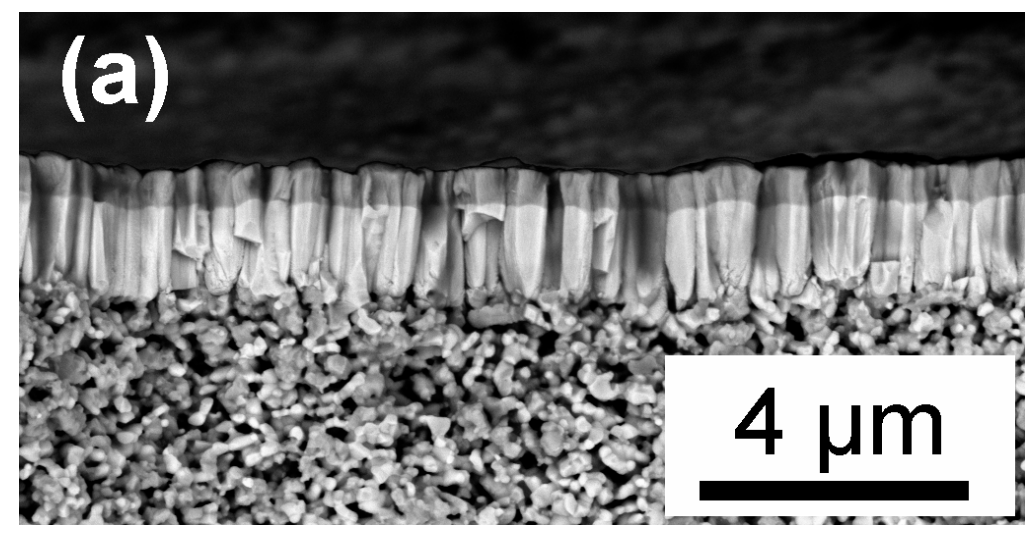

\section{ADVANCED \\ ENERGY MATERIALS}

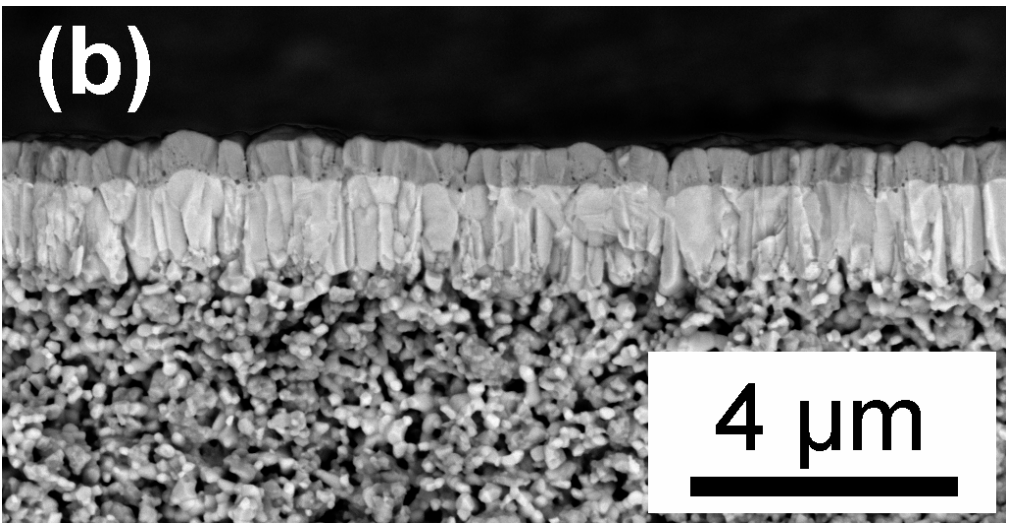

Figure S2. (a) Cross-section SEM micrograph of a sample before annealing. (b) Cross-section SEM micrograph of a sample after annealing. The film becomes denser during annealing, but does not crack. 